Kaygl, 19(II)/2020: 387-407. Araştırma Makalesi | Research Article

Makale Geliş | Received: 07.05.2020

Makale Kabul | Accepted: 26.06.2020

Yayın Tarihi | Publication Date: 15.09.2020

DOI: 10.20981/kaygi.788597

\title{
Fehmi ÜNSALAN
}

Res. Assist. Dr. | Arş. Gör. Dr. Kocaeli University, Faculty of Science and Letters, Department of Philosophy, Kocaeli, TR Kocaeli Üniversitesi, Fen Edebiyat Fakültesi, Felsefe Bölümü, Kocaeli, TR

ORCID: 0000-0003-4251-3990

fehmi.unsalan@kocaeli.edu.tr

\section{The State as a Janus-Faced Structure: Anti-Paternalism and Pastoral Power}

\begin{abstract}
The claim that "the good accompanies every political action" stands out as one of the basic claims of political philosophy. In this sense, every political action brings along the knowledge of the good, that is, the inclination towards the knowledge of the good life or the good society. It is possible to claim that there is a kind of a relationship directing the deeds of the individual as much as the validity of consideration of the government, in this context, the state as a way of domination in itself. In this study, starting from the relationship between paternal and pastoral powers, it will be attempted to show that the state has an invariable dual power structure. The relationship between the paternalist power technique with more state claims and the pastoral technique with less state claims will be tried to be laid on the evaluations of John Locke, Michel Foucault and Gerald Dworkin.
\end{abstract}

Keywords: State, Paternal Power, Pastoral Power, John Locke, Michel Foucault.

\section{Devletin İki Yüzü: Anti-Paternalizm ve Pastoral İktidar}

Öz

İyiye dair kanının her politik eyleme eşlik etmekte olduğu politika felsefesinin temel iddialarından biri olarak öne çıkar. $\mathrm{Bu}$ anlamda her politik eylem, iyinin bilgisine yani iyi yaşamın ya da iyi toplumun bilgisine bir yönelimi de beraberinde getirir. İktidarın, söz konusu bağlamda devletin, özünde bir tahakküm biçimi olarak düşünülmesinin meşruluğu kadar bireyin eylemlerini yönlendiren bir ilişki biçimi olduğunu iddia etmek de mümkündür. Bu çalışmada paternal ve pastoral iktidarlar arasındaki ilişkiden hareketle devletin değişmez bir ikili iktidar yapısına sahip olduğunu gösterilmeye; daha fazla devlet iddiasını taşıyan paternalist iktidar tekniği ile daha az devlet iddiasını taşıyan pastoral teknik arasında nasıl bir ilişki olduğu John Locke, Gerald Dworkin ve Michel Foucault'un tespitleri üzerinden serimlenmeye çalışılacaktır.

Anahtar Kelimeler: Devlet, Paternal İktidar, Pastoral İktidar, John Locke, Michel Foucault. 
Human actions are purposive and purposes are thought to be good. Plato describes the political actions as one of the most beneficial forms of "art" trying to understand the states of mind and habits of the people. (650b Plato, 1961) Political action is the reflection of anything that could be thought in the mind about politics (political idea). Then, what is the main purpose of political action? For Leo Strauss, every political action aims to either preserve or change. The preservation stems from the desire to stop an alteration that is thought to be the cause of the worse. To alter, on the other hand, is about enabling the better. Therefore, every political action is guided by a thought of better and worse. The thought of better or worse is about being inclined to be good. (Strauss, 1988, p. 10). To have an opinion, or in other words, an assumption of good, accompanies every political action. The good can be questioned via reason and become open to discussion, which takes the good out of being an opinion and leads it to become knowledge. In this sense, every political action carries intentionality towards the knowledge of the good, in other words, "the knowledge of the good life or the good society". In this sense political philosophy appears where this inclination towards good becomes clear: Good life and good society are the main purposes of political life. In this study, based on the fundamental questions of political philosophy, an attempt will be made to show that the state has an invariable dual power structure.

\section{The Fundamental Questions of Political Philosophy}

There are fundamental questions that the political philosophy and the political phenomenon have to answer: What is the state? Is the state obligatory or was it born out of a historical need? What if there hadn't been the state, what kind of a social organization would people build? This and similar questions are the fundamental questions of political philosophy. Robert Nozick claims that before these fundamental questions of the philosophy of how to organize the state, it needs to be started with the question of if the state is necessary? According to Nozick, the main area for political philosophy to come into existence is the state. Thus, there is no possibility to mention political philosophy if there is not any state: 
"Since anarchist theory, if tenable, undercuts the whole subject of political philosophy, it is appropriate to begin political philosophy with an examination of its major theoretical alternative. Those who consider anarchism not an unattractive doctrine will think it possible that political philosophy ends here as well”. (Nozick, 1974, p. 4).

Consideration of Nozick's is valid for the modern political philosophy. But same validation is not suitable for the fundamental question of the classical political philosophy which was shaped by Plato and Aristotle whether state is necessary or not:

"Classical political philosophy is nontraditional, because it belongs to the fertile moment when all political traditions were shaken, and there was not yet in existence a tradition of political philosophy. In all later epochs, the philosophers' study of political things was mediated by a tradition of political philosophy which acted like a screen between the philosopher and political things, regardless of whether the individual philosopher cherished or rejected that tradition". (Strauss, 1988, p. 27).

Before Socrates, the philosophical debate in the context of law is an extension of an ontological debate in a way that is related to justice. The first philosopher to use the concept of justice (dike) in the context of philosophy is Anaximander. According to Anaximander, justice is related to "Apeiron" and it is used in the meaning of "serving the sentence" and "being redeemed". Existences return to what they are made out of. In this way, they serve the sentence of the injustice towards each other (adikia) and they are redeemed (Peters, 1967, p. 39) The context of the definition of political philosophy by classical political philosophers has a wide scope. The main reason for this is the fact that these philosophers do not approach political things like a spectator from the outside, that the citizens and the statesmen speak the same language, and that all the terminology used by them is familiar in the Agora. (Strauss, 1988, p. 28) In this sense, the work where the characteristics of the classical political philosophy were exactly revealed can be claimed to be The Laws by Plato: This Dialogue is the conversation among an old Athenian stranger, a Cretan and a Spartan about the law and politics in Crete. The Athenian has come to Crete to examine the laws there. If the best laws are the ones created by the "elders", for a Greek, the best laws must be the laws of Crete, which are the oldest Greek laws. However, if by the term "elders", the gods or the 
favorites of the gods are not meant, it is not possible to associate the good (the law) with the elders. That's why the Cretans believe that their law's source is Zeus because they believe that the Cretan lawmaker, Minos, is trained by Zeus as his son. However, this belief has no basis other than the words of Homer. Whether the poets tell the truth or not is as controversial as the Cretan people who are notorious for telling lies. Later, the conversation shifts towards the actual worth of laws from the sources of the laws. If a law has been made by the gods or heavenly creatures, it has to be a good law. But if the god or the gods aren't the lawmakers of Crete or anywhere else, the lawmakers have to be human beings. And this changes the context of the debate. (Plato, 1961, pp. 161-169)

There are several types of human lawmakers. The lawmaker eventually has different characteristics in a democracy or in a monarchy. Under every circumstance, by the lawmaker, the administrator body is meant, and this body's main characteristic depends on the social and political order, that is, the regime. The reason for the laws is the regime. Thus, according to Strauss, the theme guiding the political philosophy is more of the regime than the laws (Strauss, 1988, pp. 33-34). What is the regime, then? The regime is the characteristics or the order of a society. The regimes have a variety of types, and this diversity and the "conflict" stemming from this diversity leads to questioning which regime is good. Therefore, the question accompanying classical political philosophy is not the question of whether the state is necessary or not which accompanies modern political philosophy; it is the question of which regime is good. After this point, ethics accompanies political philosophy.

Classical political philosophy is characterized by a basic and specific compromise. So, the aim of political life is the virtue, and the most efficient regime leading the society to virtue is the aristocratic republic. At this point, modern political philosophy differs from classical political philosophy; the classical scheme is not realistic, so it is rejected. This rejection, at the same time, functions as the common ground among the modern political philosophies. Besides, it functions as the exclusion of ethics calling for the "must" mandatorily out of the politics. Machiavelli, one of the founders of modern political philosophy, suggests that the direction of the political 
philosophy should be turned towards the aims of the societies existing actually instead of the idea of the best regime, that is, what it must be, which is only possible in a utopia. Machiavelli thinks that human beings are innately selfish in a radical way. In this case, for example, the patriotism is not in the nature of the human being and only through the education it can be gained. (Machiavelli, 2007, pp. 31-32) However, the fact that human beings are selfish by their nature is not an obstacle for their socializing or their being the entities protecting the benefits of the public. It requires the "political force" to transform a human being who is naturally selfish into a person who protects the public good. Machiavelli argues that justice can be achieved by demonstrating that injustice is something unprofitable rather than through sermons or counseling. The necessary thing for this is the institutions running properly, not virtue or moral references. Thus, the emphasis shifts from virtue or character formation to highly measurable institutions. One of the common grounds where the modern political philosophers meet is here: The aim of the society should not be set by the moral terminology but by the law terminology. The idea of the aim of the society is important. Because a society existing actually is labeled according to its aim and this aim presents a measurement in the judgement of the society.

\section{From Paternalism to Liberalism}

The question of whether the state has the right to limit the free actions of the citizen for a certain purpose is one of the basic questions of modern political philosophy. This question can be expressed in a specialized way like this: Can the state intervene in some of the behaviours of their citizens or their nationality for their good? These questions direct us to the paternalist power debate. The concept of paternalism, firstly fully discussed by John Locke, cames up again by the 20th-century thinker Gerald Dworkin systematically: Paternalism is the justification for the state to intervene in the free actions of the individual for the well-being, happiness, benefits of the individual. Thus, the laws made with this purpose cannot be considered as a violation of rights. For instance, several laws such as the law obliging the motorcycle riders to wear 
helmets, forbidding to swim in the public beaches in the absence of lifeguards, the laws counting suicide as a crime, the laws counting women's and children's work at certain jobs as illegal, the laws requiring certifications for certain jobs, the laws making people buy retirement fund with a part of their income can be shown as examples of the paternalistic limitations. (Dworkin, 1971, p. 108) ${ }^{1}$ According to paternalism, the parents have the right to limit some behaviors of their children to protect them from certain possible dangers, as children are incapable of emotional and cognitive capacity to make rational decisions. The problem is the justification of the restriction of the behaviors of adults. Paternalism considers these interventions in children valid for adults as well. Some adult individuals share the same incapability with children in terms of their capacity of knowledge and thinking rationally. Dworkin advocates that intervention in these kinds of individuals is rational. (Dworkin, 1971, p. 110) That's why in a paternalistic intervention, the desires of the ones who are exposed to the interventions are not opposed to, or their freedom is not interfered with. Because according to this approach, one might not act rationally for some reasons and with paternalistic intervention, it is ensured that they act rationally. If a person, for example, thinks that if s/he jumps down somewhere high, s/he can fly, then whether s/he should be intervened or not can be the question of the paternalist. The possible answer is that this person would not want to get hurt and if s/he can be persuaded that $\mathrm{s} / \mathrm{he}$ is wrong about his/her action, then s/he will not want to do that. (Dworkin, 1971, p. 111) Similarly, the decisions to use or not to use substances destructing the emotional and physical capacities of the individuals and causing physiological or psychological addiction can create irreversible problems. Dworkin claims that in these kinds of situations, paternalistic intervention potentially should be imposed as an insurance policy hindering us from making dangerous decisions. (Dworkin, 1971, p. 115)

This point of view is open to criticism in many aspects. What will be the limit of the decision making about what is good on behalf of the individual? John Stuart Mill

\footnotetext{
${ }^{1}$ Gerald Dworkin defined paternalism as “interference with a person's liberty of action justified by reasons referring exclusively to the welfare, good, happiness, needs, interests or values of the person being coerced". see (Grill, 2018).
} 
says that it is appropriate to apply the state's paternalism to the children, and he argues that it is a must that children are protected and controlled in different ways. On the contrary, in a civilized society, a paternalism for the adults by the state cannot be accepted. Paternalism can only be possible in case of an adult who might damage someone or has serious mental issues. (Mill, 2015, p. 13) Similarly, according to Hobbes, in a condition that the good is accepted as a norm on a social platform, what is good today can be bad some other time. Then today, a restriction for the good of the individual can be for the bad of the individual some other time. Similarly, some artistic creation processes or cultural/religious practices gain their meanings from the irrational frame for us. Here, the irrational thing might be a reason for a creation or a meaning. This point of view carries the danger of leading to an anti-democratic authority and totalitarianism. History is full of oppression examples which are claimed to have been applied for the freedom of the citizens primarily by authoritarian political leaders. For this reason, for a state having a paternalistic approach, there is always the danger of turning into a despotic state. In this case, opposing to the paternalism is being libertarian and defending freedom. In its simplest sense, negative freedom means that the individual has the state of freedom without being exposed to others' authority. (Berlin, 2002, p. 177).

John Locke, the seventeenth-century English philosopher as the father of Liberalism, draws a resemblance between the paternalist way of power and the monarchy. Locke discusses the paternal power, the relationship between the parents and the child as a form of society. This kind of society is quite different from political society. Locke puts forward the idea that the terminology of paternal is derived from the power of the parents over their children, but that it has a dilemma as if the mother has no share in this power at all. Paternalism gives the power to the hands of the father. However, both the logic and the revelation indicate that the mother has equal rights as much as the father in this power. Therefore, it makes us ask if it is more appropriate to call it parental power instead of paternal power. (Locke, 1980, pp. 30-31) For example, in the case that a woman can be married more than one man, in the case that when the 
couple get divorced and the children's custody is given to the mother or when the children are at a very young age, the father dies, since the parental power will belong to the mother more, the concept of paternal power loses its meaning and instead, the concept of parental power should be used.

Although all people are equal by nature according to Locke, it isn't equality that is absolute and put forward by the early modern rationalists. Because the features like age and virtue can provide the human with a valid priority. By "equality", negative liberty is meant in which without depending on another person's authority or willpower, every human has their natural freedom equally. (Locke, 1980, p. 34) Locke thinks that children are equal in terms of being born, but that they aren't born into equal conditions. After their children are born, parents have a power and and authority over them (Locke, 1980, p. 34) Different from paternal power, parental power over children is not permanent but temporary. As age and mind develop, the individual is left alone with his/her thoughts and self. ${ }^{2}$ Though the authority the parents have is a right, actually it is a responsibility. Locke justifies the idea that children need parental power with theological discourse. According to him, in the beginning, Adam was created as a perfect man with all his features and from the first moment of his existence, he was capable of self-governance of his actions with the laws of logic instilled by God. However, after Adam, the earth was populated with his descendants. "Everybody in these descendants who is ignorant and incapable of comprehension is born as weak and hopeless children (Locke, 1980, pp. 32-35). According to Locke, all parents are

\footnotetext{
${ }^{2}$ According to Hobbes, the source of the power of the parents over their children is that the child expresses his/her consent through direct implications. In this sense, it is similar to Locke's thought. For Hobbes, the mother has the right to parent as much as the father. However, it is not possible to talk about a partnership between mother and father. Despite the equality of relations between men and women, it is explained that the power belongs to the father: "God hath ordained to man a helper; and there be always two that are equally Parents: the Dominion therefore over the Child, should belong equally to both; and he be equally subject to both, which is impossible; for no man can obey two Masters. And whereas some have attributed the Dominion to the Man onely, as being of the more excellent Sex; they misreckon in it. For there is not always that difference of strength or prudence between the man and the woman, as that the right can be determined without War. In Common-wealths, this controversie is decided by the Civill Law: and for the most part, (but not always) the sentence is in favour of the Father; because for the most part Common-wealths have been erected by the Fathers, not by the Mothers of families" (Hobbes, 1996, pp. 139-140). See also for detailed discussion; Sema Ülper Oktar (Oktar, 2007, p. 85).
} 
responsible for protecting, feeding and educating their children until this desperation is eliminated by aging. Here, Locke merges his epistemology which has the most empirical justifications with a theological argument. To Locke, the law to which Adam is subjected is valid for all his breed and it is the law of reason. (Locke, 1980, p. 35) However, different from Adam, his breed is given birth and reproduction through birth is realized without reason and in an instinctive way. Being born without reason is originated by Locke's epistemological idea that" the human mind is a blank slate (tabula rasa) innately". To be clearer, a human who is deficient of thought cannot be imposed by this law. Since the law is made to be known and declared only through the reason, someone who doesn't use the reasoning yet is not under its enforcement. Since the children of Adam, children are not free as well because they are not under the enforcement of the law of reason that they were born into:

"For law, in its true notion, is not so much the limitation as the direction of a free and intelligent agent to his proper interest, and prescribes no farther than is for the general good of those under that law: could they be happier without it, the law, as an useless thing, would of itself vanish; and that ill deserves the name of confinement which hedges us in only from bogs and precipices. So that, however it may be mistaken, the end of law is not to abolish or restrain, but to preserve and enlarge freedom". (Locke, 1980, p. 32)

The thought that the law is not a restriction or a limitation of freedom is a tradition prevalent through modern legal philosophy. Although this tradition paves the way for the twentieth-century paternalists to have a basis, it allows Locke to deem the law to be wrong and makes it possible to rethink the relationship between the laws and freedoms. Since, just like Locke claims, any kind of law is better than being without any law, is it possible to accept the authoritarian law justifiable instead of being without any law? In other words, can it be easily said that the worst state is better than the best statelessness? At this point, the reasoning that Nozick uses while questioning the ontological foundation of the state can be brought into question. Nozick thinks that the question whether the existence of the state is compulsory or not, which is defined as the basic question of political philosophy and might be seen as the basic question of modern political philosophy, can be answered through the state of nature examination. 
According to Nozick, the main reason for this question is the productivity of this theory, its being comprehensive and arousing interest (Nozick, 1974, pp. 3-6). Besides, if the situation of statelessness is terrifying, then instead of dismantling a state and putting nothing in its place will mean activating a disaster and it will form a legal ground for the idea of the state. On the other hand, if it is shown that the state is superior to even the best anarchy situation which is hoped to be realistic, which can only be Locke's state of nature $^{3}$ appearing as a conclusion of a process which has no phase that isn't allowed by morality and this is an improvement, this will be a justification for the existence of the state and it will show the state as justifiable. (Nozick, 1974, p. 5) Just as the moral law is a prerequisite for Kantian freedom, in Locke's political theory, the positive law is the precondition for freedom. So, humans become free when they reach the rationality which enables the law that will govern them to show the way and enables them to know the willpower belonging to themselves. According to Locke, human beings do not have willpower belonging to themselves and which they can go after when they lack cognition belonging to themselves to govern their willpower. For this reason, it's a right and responsibility that the parents having cognition to use their willpower instead of the child lacking the cognition or rational thinking. However, the paternalists, such as Dworkin, claim that the right of interference to the individuals lack of thinking rationally is legal. Here, the problem is whether the actions of people having cognition can be restricted or not. As we stated above, because any kind of law is better than no law at all, the people under any kind of law will not be regarded as restricted. The basic theory of paternalism is the restrictions of irrational behaviors and according to them actually, these restrictions (freedom, as long as defined by the law) makes people free, let alone depriving them of their freedom. In this case, there are traces of a paternalist approach in the definition of the law by Locke. According to Locke, the thing that makes human independent of the law of nature gives human their property, the right of

\footnotetext{
${ }^{3}$ Besides, at this point, in the state of nature philosophy of Locke, we can conclude that the state of nature is a state of liberality but not freedom/independence: "But freedom is not, as we are told, a liberty for every man to do what he lists: (for who could be free, when every other man's humour might domineer over him?) but a liberty to dispose, and order as he lists, his person, actions, possessions, and his whole property, within the allowance of those laws under which he is, and therein not to be subject to the arbitrary will of another, but freely follow his own" (Locke, 1980, p. 32)
} 
possession of their freewill staying in the scope of this law is the maturity situation in which it is assumed that humans have the capacity to know this law, and thus they can keep their actions in the limits of the law. (Locke, 1980, p. 33) According to this, it is assumed that when a human has reached maturity, s/he knows how much the law can help him/her and they know how much of the freedom s/he can use. Of course, the problem is not only reaching a certain age. For example, if an individual, because of some possible disabilities, hasn't reached the reasoning level assumed as the ability to know the law and thus, to know that they are subjected to the law, according to Locke, that individual hasn't reached the state of being a free individual. So, the circumstance of freedom depending on the law is something beyond the age; it is a situation of rationality. This rationality's border is to know the laws that are offered to someone and to accept living under law. Then, another condition of freedom is the knowledge of the law. That's why the insane people and retarded people are never freed from their parents' control (Locke, 1980, p. 34)

Where it is assumed that the individual becomes free with the law, there the law replaces the parent. However, the law doesn't behave in the same way that the parents behave towards the child. In Second Treatise of Government, Locke's moving on to the section titled "On the Political or Civil Society" after discussing the concept of paternal power is meaningful in this context: The states automatically realize that there is a specific time for a person to start to act like a free person and let them act like they are free people. As it is stated before, the paternalist way of thought looks for its foundation for the mentioned rightfulness of the intervention in its intervention in the rational individual. Nevertheless, it is seen that the issue of at what age the rational individual is going to reach the rationality has opened a new critical door to paternalism. The fact that the acknowledgement of rationality differs from one state to another makes it harder to mention about reaching out universal rationality. 


\section{The Limits of Paternal Power}

According to Locke, the attention that has to be shown by the parents towards the children shouldn't be turned into the father's absolute and arbitrary sovereignty. The power of parents over children should be carried on in the best way for them to be beneficial both for themselves and for others. It cannot go beyond the efficient discipline practices that will provide physical and mental vigor. In the case of obliging the father's conditions, with the aim of the children to maintain their existences, what is beyond making them work is not possible. This power is all about help for the childhood deformations and weaknesses to be eliminated and a practice needed for the children's education. The sovereignty of the father cannot reach out to the lives and the goods - let them be gained by them or be donated to them - belonging to the children. For Locke, the right to life and own property is absolute; it is in a realm that even parental power cannot touch. Another right which is unreachable for the power of the father is the right to citizenship the child gets when he/she understands that s/he lives under the law and s/he reaches the state of rationality where s/he can separate the good from the bad:

\footnotetext{
"But these two powers, political and paternal, are so perfectly distinct and separate; are built upon so different foundations, and given to so different ends, that every subject that is a father, has as much a paternal power over his children, as the prince has over his: and every prince, that has parents, owes them as much filial duty and obedience, as the meanest of his subjects do to their's; and can therefore contain not any part or degree of that kind of dominion, which a prince or magistrate has over his subject". (Locke, 1980, p. 39).
}

Although there are resemblances between the family as a community and the state as a civil society, the family and the state are different from each other in terms of power and aim. Although the family is thought as a monarchy and the householder is thought as the monarch, the fact that the power of the householder over his people is restricted in an obvious and different way in terms of time and size makes the absolute monarchy a broken and restricted power: 


\begin{abstract}
But because no political society can be, nor subsist, without having in itself the power to preserve the property, and in order thereunto, punish the offences of all those of that society; there, and there only is political society, where every one of the members hath quitted this natural power, resigned it up into the hands of the community in all cases that exclude him not from appealing for protection to the law established by it. (Locke, 1980, p. 46)
\end{abstract}

The reason for existence and the existential basis of the modern political society is the fact that people give up on their natural freedom so that their properties are protected. The place where the people give up on the right to execute the natural law and transfer this right to the public domain, join in society to create political integrity under an independent government is the civil society. For a society to be called civil society, it must have a judicial authority to resolve the disputes and to punish the aggressions with a law that is common and established. Again, with the same reason, the laws should be made in the way that is required by the public good. As a commonwealth, the state has the right to punish its own citizens if a crime is committed because of the disagreements between them as much as the right to punish a non-citizen damaging one of its citizens. According to Locke, the aim of all the powers is to protect the property of all the members of the society as much as possible. Because the aim of civil society is to erase the inappropriatenesses of the state of nature stemming from the fact that every person is their own judge, to create an authority compulsory for every member to obey and can be consulted in the case of disagreements, in the situations of no such authorities to erase the disagreements; for example, in absolute monarchies under the absolute prince's sovereignty, people cannot get out of the state of nature. For this reason, the absolute monarchy is not a civil society state. The civil society is a society that gives people their individuality and makes them civilized. Through civil society, individuals become the subject in front of the laws made by them. Diseases which are exposed to allow people to get protection under the law of the governments and there makes them aim to protect their properties.

According to Locke, as their inclusion to society is using their properties in peace and security, people need the laws which can achieve these goals. Even in monarchies, there are judges to whom people can consult to solve the disagreements among each 
other. However, in monarchies, the situation is different from the state. In the relationship between the absolute monarch and his/her nationality, the monarch almost sees his/her nationality as his/her animals doing beneficial work for him. However, in a family, this kind of relationship between the parent and the child is not in question:

\begin{abstract}
"In absolute monarchies indeed, as well as other governments of the world, the subjects have an appeal to the law, and judges to decide any controversies, and restrain any violence that may happen betwixt the subjects themselves, one amongst another. This everyone thinks necessary, and believes he deserves to be thought a declared enemy to society and mankind, who should go about to take it away". (Locke, 1980, p. 50).
\end{abstract}

The lawmaker is like the householder of the family looking after his/her family's interest. Just as the power of the father over his child is to educate them to empower them and to feed them, the power of the lawmaker's aim is to secure the protection of the people. Just as the father has no right to touch any of the property left from others to the child or to make no law about the life of the child, no lawmaker has the right to make their citizens enslaved or destroy them. The power of the father over his child is, by its nature, in harmony with the law of God. The laws made by the lawmakers should be proper for the law of nature for the other people as much as their actions, in other words, they should be proper for the divine will. Here, the father and the son are equal subjects.

Karl Marx, in his criticism On the Jewish Question, while criticizing the concepts of equality, liberty and property, mentions about the atomized and monad-like look of the civil society individuals. Citing the rights of the civil society people from the 1793 French Constitution, Marx criticizes the principle that freedom is the right of doing anything without damaging others' rights:

"Liberty, therefore, is the right to do everything that harms no one else. The limits within which anyone can act without harming someone else are defined by law, just as the boundary between two fields is determined by a boundary post. It is a question of the liberty of man as an isolated monad, withdrawn into himself ... But the right of man to liberty is based not on the association of man with man, but on the separation of man from man. It is the right of this separation, the right of the restricted individual, withdrawn into himself". (Marx, 1843, p. 163) 
Modern period paternal power debate primarily focusing on the protection or property shows itself as the debate whether citizen supervision is legal or not. The evaluation above which Locke's criticisms are at the center of points out the problems of the idea of paternalism in the context of liberal thought. According to this, it is possible to say that the paternal idea is identified with the conservative idea and directly with the state, and in contrast, the liberal inclinations are distant to this theme. However, it is enough to take a look at the concept of pastoral power in order to see that this point of view is actually problematic.

\section{Pastorality as the Individualizing Power}

Michel Foucault claims that the power techniques are headed more and more towards the individuals during the process and aim to manage the individuals in a continuous and permanent way. While he labels the political way which is central and centralizing as the state, he labels the individualizing power moving with it as pastoralism ${ }^{4}$ The idea of divine being, the king or the leader, as a shepherd with the herd in the pastoral sense, is something the Greeks and Romans do not know. According to Foucault, herd metaphor is rarely encountered in Greek or Roman political literature. Nonetheless, in the ancient eastern societies like Egypt, Assyria and Palestine, these metaphors can be encountered very often:

"Pharaoh was an Egyptian shepherd. Indeed, he ritually received the herdsman's crook on his coronation day; and the term 'shepherd of men' was one of the Babylonian monarch's titles. But God was also a shepherd leading men to their grazing ground and ensuring them food. An Egyptian hymn invoked Ra this way: "O Ra that keepest watch when all men sleep, Thou who seekest what is good for thy cattle...." The association between God and King is easily made, since both assume the same role: the flock they watch over is the same; the shepherd-king is entrusted with the great divine shepherd's creatures. An Assyrian invocation to the king ran like this: Illustrious companion of pastures, Thou who carest for thy land and feedest it, shepherd of all abundance". (Foucault, 1981, pp. 227-228)

\footnotetext{
4 The concept of pastoral used by Foucault is derived from "pastorate", "pastor"; "pastor" means shepherd, priest, guide and usher.
} 
The Hebrew are the ones who have improved and expanded the pastoral theme: There are notions of shepherdlike qualities in the construction of the power. For example, the shepherd rules a herd rather than a geography or a piece of land. Nevertheless, the Greek Gods are the essential owners of the geography and in fact, this basic property defines the relationship between the humans and the Gods According to Foucault, here the main thing is the relationship between the Shepherd-God and his herd. So, God bestows or promises a piece of land upon his herd. Another aspect of the shepherd is collecting the whole herd and leading them as an usher. There is also the idea that political leaders can secure integrity over the conflicts by erasing any kinds of hostility inside the site borders. However, what the shepherd brings together are scattered individuals. These scattered individuals come together when they hear the voice of the shepherd:

Conversely, the shepherd only has to disappear for the flock to be scattered. In other words, the shepherd's immediate presence and direct action cause the flock to exist. Once the good Greek lawgiver, like Solon, has resolved any conflicts, what he leaves behind him is a strong city with laws enabling it to endure without him. (Foucault, 1981, p. 229).

The shepherd's duty is to assure the salvation of the herd. Greeks in a similar way believe that the site is protected by the Gods. However, Foucault highlights the way that the shepherd rescues his herd. According to that, while in Greece, the saviour attempts to save when they are on the verge of danger, the shepherd's duty of saving shows a continuous, individualized and compassion with a goal:

Constant kindness, for the shepherd ensures his flock's food; every day he attends to their thirst and hunger. The Greek god was asked to provide a fruitful land and abundant crops. He wasn't asked to foster a flock day by day. And individualized kindness, too, for the shepherd sees that all the sheep, each and every one of them, is fed and saved. (Foucault, 1981, p. 229).

Locke sees the example of compassion that Foucault sees in the notion of shepherd on the basis of the pastoral techniques in the parent through the appliance of the paternal power: 


\begin{abstract}
"The nourishment and education of their children is a charge so incumbent on parents for their children's good, that nothing can absolve them from taking care of it: and though the power of commanding and chastising them go along with it, yet God hath woven into the principles of human nature such a tenderness for their off-spring, that there is little fear that parents should use their power with too much rigor; the excess is seldom on the severe side, the strong bias of nature drawing the other way. And therefore God almighty when he would express his gentle dealing with the Israelites, he tells them, that though he chastened them, he chastened them as a man chastens his son".(Locke, 1980, p. 37).
\end{abstract}

Another difference between the shepherd from the political leader is the thought that the shepherd's usage of power is his duty. Just like the father's usage of power is a responsibility along with a right. The shepherd takes every step thinking about the good of the herd. When everybody falls asleep, the shepherd waits up for the herd. According to Foucault, this theme of watch duty is important. This reveals two dimensions of the devotion of the shepherd. While the former one is acting for the people whom he feeds and who are sleeping, the latter one is caring for them. He takes care of each of them individually. This situation puts another burden on the shepherd. This burden is knowing his own herd both totally and in detailed behaviors. According to this, he not only has to know where the good grassland is, the laws of seasons and the order of things, but he also needs to know their personal needs:

One is that the Homeric poems use the shepherd metaphor to refer to the kings ... The word nomos (the law) is connected with the word nomeus (shepherd): The shepherd shares out, the law apportions. Then Zeus is called nomios and nemeios because he gives his sheep food. (Foucault, 1981, p. 231).

Plato also mentions a shepherd-judge. Especially in the Statesman, he examines this subject thoroughly. According to Foucault, there might be two reasons for this. This is either a common point of view in those days, or Plato is discussing one of the Pythagorean themes. It makes the second reason more plausible because there is no other metaphor of shepherd in any other contemporary political texts. While Plato is investigating the statesman and trying to show whether the manager of the site can be a commander or a shepherd, he uses the method of distinction. With the effort of reaching the statesman, he makes distinctions between the human commanding the inanimate 
things and the human commanding the animals, between the human commanding the animate animals and the human commanding the herds, between the human commanding totally the herds and the human commanding the human herds. Here, he determines the political leader as the shepherd of the people. However, since this method making people and all the other animals confront each other is not a good way, he starts to debate again and expands the distinction in an infinite way. The distinction is expanded as between the wild animals and the pets, between the animals living underwater and the animals living on land, between the animals with horns and the animals with no horns, between the animals with double hooves and the animals with straight hooves, between the animals who can mate among themselves and the ones who cannot and so on (Plato, 1997, p. 267b ff) For Foucault, what the initial improvements and later failure of the dialogue shows is that the distinction method cannot prove anything when it is not used properly. (Plato, 1997, p. 233) Foucault's evaluation is not new, because Aristotle, while criticizing Plato's Statesman, says that although Plato thinks that "the relationships between the statesmen and the state, between the king and his nationalities, between the householder and the household, between the master and their slaves are the same", which he is wrong about. According to Aristotle, between these, the only difference is not greatness but also there is a quality difference and the greatness is not a distinction. Because we cannot say that there is a master-slave relationship between a man and a few people, a family relationship with more people, and a kingdom or a political society relationship with more people than that. Besides, when the duties of the shepherd and the Greek political leader are compared, as well, it is understood that the Greek political leader isn't the shepherd and the pastoral technique doesn't belong to that period. The administrator's duty is not providing the needs of people. This duty is performed by different citizens (farmers, bakers, doctors, physical education instructors). The duty of the Greek politician is to create the site union and to secure it, not to support the lives of a group of individuals. These actually are the exact things that the libertarians don't want more in a state they called minimal state or night watch, the things that the more is inconvenient in terms of morality and detains the state from showing being excused. In short, according to 
Foucault, whereas the political issue in the Greek focuses on the relationship between the site and a person and a few people in the frame of its citizens, the pastoral issue is about the lives of the individuals.

Foucault thinks that Christian pastoralism contains a private knowledge between the priest and each of his sheep. This information is individualizing. So, it isn't enough to have knowledge about the situation of the herd, information about each and every sheep should be known individually. Be it liberal or totalitarian, in a modern state, for example, information of the state about an electric bill and almost all personal information of an individual, from the citizen's address to their sex, are the same:

\footnotetext{
"We can say that Christian pastorship has introduced a game that neither the Greeks nor the Hebrews imagined. A strange game whose elements are life, death, truth, obedience, individuals, self-identity; a game which seems to have nothing to do with the game of the city surviving through the sacrifice of the citizens. Our societies proved to be really demonic since they happened to combine those two games - the city-citizen game and the shepherd-flock game - in what we call the modern states". (Foucault, 1981, p. 239).
}

The improvements in the pastoral technology devastate the ancient society's political constructions. According to him, political rationality has improved and made itself accepted in western societies. Political rationality has found its first foundation in the idea of pastoral power, later, it has leaned on the mind of the state, consequently, on the paternalism.

\section{Conclusion}

In this study, an attempt has been made to show that the state, which has been mentioned the most for centuries and which is the most magnificent but at the same time the most doubtful management technique, has maintained its existence as both a totalitarian and individualizing political device from the very beginning. It can be said that the paternalist power having the discourse of more state and the pastoral technique defending the discourse of less state, with a Foucaultian expression, are actually the two faces of the structure called the state in power play. It is possible to claim that the 
power, in this context the state, is a kind of relationship that directs the individual's actions as much as it is legal to be thought as a way of domination. In this dual context, the criticism of power or the thing that is needed for getting free from the state power in the meaning of a political protest, requires a questioning of the techniques that have been discussed in this paper. 


\section{BIBLIOGRAPHY}

BERLIN, I. (2002). Two Concepts on Liberty. In H. Hardy (Ed.), Liberty: Incorporating Four Essays on Liberty.

DWORKIN, G. (1971). Paternalism. In R. A. Wasserstorm (Ed.), Morality and Law (pp. 107-126).

FOUCAULT, M. (1981). Omnes et Singulatim: Towards a Criticism of Political Reason. In S. M. McMurrin (Ed.), Tanner Lectures in Human Values. Salt Lake City: University of Utah Press.

GRILL, J. H. a. K. (2018). Introduction The Routledge Handbook of the Philosophy of Paternalism: Routledge.

HOBBES, T. (1996). Leviathan (R. Tuck Ed.): Cambridge University Press. Company.

LOCKE, J. (1980). Second Treatise of Government: Hackett Publishing

MACHIAVELLI, N. (2007). Discourses On The First Decade Of Titus Livius. United States: Dover.

MARX, K. (1843). The Jewish Question Collected Works: Karl Marx, Frederick Engels (Vol. III (1843-1844)). Philp Ed.).

MILL, J. S. (2015). On Liberty, Utilitarianism and Other Essays (F. R. Mark

NOZICK, R. (1974). Anarchy, State And Utopia. USA: Basic Books.

OKTAR, S. Ü. (2007). Kadın Sorunu Açısından Bir Felsefe Tarihi Okuması. (masters), Kocaeli University, Kocaeli.

PETERS, F. E. (1967). Greek Philosophical Terms: A Historical Lexicon. New York: New York University Press. Ltd.

PLATO. (1961). Laws Volume: I (R. G. Bury, Trans.). UK: William Heinemann

PLATO. (1997). Complete Works. Indianapolis: Hackett Publishing Company.

STRAUSS, L. (1988). What is Political Philosophy and Other Studies. Chicago: The University of Chicago Press. 